\title{
TRANSACTIONS
}

OF THE

\section{ROYAL SOCIETY OF EDINBURGH}

VOL. LXVI-No. 16

1965-66

\section{DISTRIBUTION IN SOME SCOTTISH SOILS OF AN INORGANIC GEL SYSTEM RELATED TO “ALLOPHANE"}

BY

J. H. KIRKMAN, B. D. MITCHELL AND R. C. MACKENZIE

[With Five Text-Figures, AND Four Tables]

PUBLISHED BY THE

ROYAL SOCIETY OF EDINBURGH

22 GEORGE STREET

EDINBURGH 2

1966

Price Fourteen Shillings 